\title{
THE NIGERIA 1999 ECONOMIC POLICY AND OBJECTIVE: AN UNFULFILLED MISSION OF EXPECTATION
}

\section{A. T. Oyewo}

\author{
Ajagbe Toriola Oyewo \\ Professor A. Toriola Oyewo Ph.D (Law), Ph.D (Admin). MPA, M.phil, MA, MILGA ACIS, \\ FCE (Nig.) FCE (Ghana) BL, \\ Jp, Profesor of Law, Lead City University, Ibadan. \\ www.facebook.com/pages/Moboluwaduro-Chamber-by-Prof-Ajagbe-Toriola-Oyewo
}

\begin{abstract}
The 1999 Constitution of Nigeria contains beautiful provisions for economic policy and objective under chapter two of the country's fundamental objectives and direct principles of the state policy. And by section 16 of the said Constitution, the economic objectives of the state are well spelt out that if followed to the letters, Nigeria would have been a paradise on earth and a country to be recognized as a developed nation. But alas, the operators of the Constitution have woefully failed in this direction. Thus the majority of the people in Nigeria are left to wallow in despicable hunger, unemployment, poor living condition and lack of many indices of social and welfare developmental services.

The condition is so bad that unless all these unpalatable and monumental factors are well addressed, the country may sooner or later reach its waterloo of extinction.

\section{Introduction}

The people of the Federal Republic of Nigeria have made a Constitution in 1999 for the purpose of promoting the good government and welfare of all persons in their country on the principles of freedom, equality and justice, and for the purpose of consolidating unity among themselves.

It must be noted however that CHAPTER II of the said Constitution deals with the FUNDAMENTAL OBJECTIVES AND DIRECTIVE PRINCIPLES OF STATE POLILCY, while section 16 of it deals essentially with the economic objectives of the state.

The provisions in section 16 may be stated essentially in a nutshell as follows:

1. That the state should control the resources of the Nation in such a way as to promote national prosperity for every citizen on the basis of social justice and equality of status and opportunity.

2. That the state should control the national economy in such manner as to secure the maximum welfare, freedom and happiness of every citizen on the basis of social justice and equality of status and opportunity.

The state should protect the right of every citizen to engage in any economic activities outside the major sectors of the economy.

3. Lastly it is provided that the state shall direct its policy towards ensuring

(a) The promotion of a planned and balanced economy.

(b) That the material resources of the nation are harnessed and distributed as best as possible to serve the common good.

(c) That the economic system is not operated in such a manner as to permit the concentration of wealth or the means of production and exchange on the hands of few individuals or a group; and

(d) That suitable and adequate shelter, suitable and adequate food, reasonable national minimum living wage, old care and pensions, and unemployment, sick benefits and welfare of the disabled are provided for all citizens.
\end{abstract}




\section{THE NIGERIA 1999 ECONOMIC POLICY AND OBJECTIVE: AN UNFULFILLED MISSION OF EXPECTATION}

As laudable as these provisions are, it must be observed that over the successive years, Nigeria has been contending herself with how to achieve these beneficial objectives which have become a pye in the sky or a sciciphean task to achieve.

One may in fact pontificate that Nigeria is a failed state; and it remains so since year 2012 to date as one of the world's failed states because the country is weak, heavily corrupt with inefficient governmental control, lack of visionary leaders with integrity, insecurity of an unyielding proportion, which has made sustainable development impossible, greed, nepotism and favouritism with confrontational attitude to both the rule of law and due process, high handedness with a serious blow to the administration of justice. In fact nothing has worked very well in Nigeria to give economic democratization or emancipation and happiness of the generality of its people a chance. Millions of its people are jobless and many are living in abject poverty without any hope for the future.

Thus there is no economic democratization to deal with the empowerment and elevation of the people to perform and transform the economy.

All these failures are indices of bad government and they glaringly show that political democratization and economic democratization are off course and strange bed fellows in Nigeria, whereas they are to be necessary co-adjutors and indeed complimentary to each other. These defects have become the albatross and touch stone of our underdevelopment in Nigeria which is the talking point of this paper and why the economic objectives have become a farce and an unfulfilled mission of expectation.

\section{An Over view of corruption}

As I have written somewhere else ${ }^{1}$ the issue of corruption has the most serious implication on good governance and sustainable development in Nigeria.

Corruption is a dreadful phenomenon which destroys the fabrics of all governmental structures in a nation. It is a canker-worm, an anathema, and a gall and worm wood entity which should be abhorred by any nation that wants progress and development. But in Nigeria, the insatiable appetite for corruption has become an endemic disease which has brought concomitant sufferings, untold economic dilapidation, unrest, poverty and lack of infrastructural facilities and underdevelopment to the people so much that the dividends of democracy are not earned and the country's economic objectives have become an illusion.

The corruption has weakened all democratic processes in the Local, State and Federal Levels of government in Nigeria. It has dampened morality, weakened meritocracy, and produced an avalanche of misrule, selfishness, ineffectiveness, colossal misappropriations of funds and unwillingness of those who were elected into governmental powers to quit their offices as at when due. It must be noted that since democracy and corruption are strange bedfellows hence Nigerians are living in a world of grinding poverty where infrastructural facilities are nil, but accumulation of wealth by those people at the helm of affairs abound; bribery for budget approval and acts of embezzlement are predominant so much that one may be worried about the future of the country unless something positively backed up with functional and punitive laws are put in place.

According to Ahmed El-Rufai (2011) ${ }^{2}$, "the endemic nature of corruption in Nigeria has led to the loss of US 380 billion between independence and 1999. A global financial integrity initiative report dated January 2011 estimated the U.S. \$130 billion worth of illicit financial flows occurred between 2000 to 2008. Adding all these numbers to the loss of nearly 87 billion to the fuel subsidy racket alone brings our national loss due to corruption to something in the region of US $\$ 000$ billion from independence to end of 2011". However, Oyewo $(2011)^{3}$ remarked that corruption is more under the military than the civilian regimes in Nigeria as follows:

During Buhari's regime which took place between 1983-1985, corruption was intense so much that his "diversification of the economic policy became a mere dream, while the "essential raw materials within a targeted period" which he promised were yet to descend from heaven ."Also the labour intensive project and job opportunities he promised were a 
mere broadcast, while his policy of rephrasing development projects involving large foreign exchange commitment was a mere fallacy, and the upholding of the principle of public accountability was a facial exhibition. The regime was so corrupt without a definite policy, it was dilly-dallying, tottering and perambulating until he was swept off the podium of power.

Gowon's government was also too corrupt. Cases of corruption perpetrated by the governors and cabinet members under him were too alarming, yet he wanted to stay put in power.

In Abacha's regime which took place between 1993-1998, corruption pervaded the entire Nigerian scene, the economy became totally crumbled, unhappiness enveloped the entire nation, while looting and arson became the order of the day. Abacha amassed wealth for himself, family and associates with downright abuse of powers and corruption while he invented machineries for the killing of people who were opposed to his further stay in office.

The story of corruption is long and depressing so much that Nigeria has been ranked among the three most corrupt nations in the world with adverse consequences on both economic and political development of the country. Corruption has eroded governmental legitimacy of Nigeria and it is a terrible blow on development of any kind.

Unless there is an integrated National assault on this hydra headed monster called corruption, Nigeria may sooner or later with accelerated speed reach its waterloo of extinction. It is therefore the talking point of this paper that unless good government are put in place the realization of the 1999 Economic Objectives will be a mirage.

\section{Corruption, Government and Economic Objectives}

Corruption has become endemic in Nigeria and since 1999 to date, it has now reached a level of cacophonic crescendo which has made the realization of her economic objectives a farce. Corruption so far appears like an inheritance of dubious value from one government to the other in Nigeria, whereby each successive government gets itself really involved in it with new machineries, gadgets and techniques to outwit its predecessor in the shoddy and nefarious act. The resultant effect of the scenario has produced a bad government which is insensitive to the plights of the common man.

Thus money that would have been used to improve socio-economic factors like water, housing, good living conditions, employment and the payment of pensions have been dangerously diverted, plundered and looted to satisfy few individuals, their privies and cronies.

It is the belief of this paper that a good government provides and pursues vigorously security, basic necessity of life, sound political and social policies which are necessary for sustainable development of its country. Thus socio-economic policy and objectives which impoverish the people through corruption in Nigeria cannot be seen to be coming from a good government.

\section{Leadership traits and politicians}

With all these written above, it then means that if we should do away with corruption completely, then Nigeria would need democratic and visionary leaders who know that political sovereignty is but a mockery without the means of meeting poverty, unemployment, illiteracy bad housing, diseases and so on.

Thus we need such leaders who believe that the happiness of a society is the end of government.

How then can our economic policy and objectives succeed in Nigeria when millions of our people are wallowing in streams of poverty, lack of care, and poor living conditions without employment? Many of our leaders in Nigeria fail to grasp the very essence of government which consists in a strong belief that offices are public trusts that are bestowed for the good of the country and not for the benefits of themselves as such. Thus, they must shun and stop the ugly ambition of amassing wealth to themselves and their cronies at the expense of the down trodden masses who have been deprived of the basic amenities of life to make a living. 


\section{THE NIGERIA 1999 ECONOMIC POLICY AND OBJECTIVE: AN UNFULFILLED MISSION OF EXPECTATION}

And how can the control of the National economy in such a manner as to promote the welfare, freedom and happiness of every citizen on the basis of social justice and equality of status and opportunity materialize in Nigeria, when there are acts of inequality between those in power as against the millions of the masses who are really suffering in silence?

No wonder why Patrick Wilmot has concluded that Nigeria has been a failure since nothing works from health, education, manufacturing, telephones, roads and many more to mention a few.

That is why Nzeogwu in January 1966 said -

"Our enemies are the political profiteers, swindlers, the men in high and

low places who seek bribes and demand ten percent, those that

seek to keep the country divided permanently so that they can remain in office as ministers and VIP's of waste, the tribalists, the nepotists".

Achebe also blamed the problems of Nigeria on the failure of effective leaders as follows -

"The trouble with Nigeria is simply and equally a failure of leadership.

There is nothing basically wrong with the Nigerians land or climate or water or anything else. The Nigerian problem is the unwillingness or inability of its leaders to rise to the responsibility; to the challenges of personal example which are the hall marks of true leadership".

One may argue that the prevailing disparity between the few "Haves" and billions of "Have-nots" may sooner or later promote conflicts between the duo which may escalate to insecurity - since an hungry man is an angry man.

Nwoke puts it right when he said as follows -

"Inequality is a potential threat to the national security, that is to the stability and continued existence of Nigeria as a Nation. This is because the prevalence of poverty, ignorance, disease and so on among the masses in Nigeria is a fertile ground for the spontaneous eruption of violence among the masses; a violence which can be triggered off by even a minor problem. A hungry man, they say is an angry man, A poor angry people forces".

in fact can also be incited to acts of disaffection and rebellion by external or internal

All the above show in clear terms that our leaders must be people oriented and put into practice all the provisions of the economic objectives as enshrined into the 1999 Constitution for the happiness of the people and sustainable development in Nigeria.

Our political leaders must therefore shun primitive accumulation of wealth to themselves, privies and cranies.

They must be law abiding and shun actions that may be translated as being partisan and evil deeds. They must look themselves as Caesar's wife who is above suspicion.

For instance, a situation credited to the President by Hon. Tambuwal in the paper titled the Nation of Tuesday, 10 December 2013, and that of Dapo Thomas of the same paper "on Sunday 8 December 2013 looks very disturbing. According to Tambuwal, Jonathan antigraft fight is weak. He alleged that the President body language was promoting corruption adding that the administration has not addressed high-profile corruption cases in the country.

He buttressed his allegation with such cases like the subsidy probe, the pension, the SEC bribe and the bullet-proof car cases.

He noted that after the House of Representative has done a diligent job by probing and exposing the culprits, you now see something else when it comes to prosecution. And instead of allowing the EFCC to be in control and prosecute the offender, Mr. President would set up another committee to duplicate a job which has already been done by the parliament.

Thus sacred cows will be protected against the provisions of the law.

He concluded that the government has no business setting up any administrative committee in such cases that are clear to all Nigerians. 


\section{A. T. Oyewo}

In his own writing Dapo Thomas queried as follows:

"With the audacious and brazen looting going on in Jonathan administration

why should the citizens who are the victims of the misery created by the

extra-ordinary corruption in government not protect or be at war with Jonathan".

Dapo pointed out that at the $1^{\text {st }}$ Nigerian Economic Summit in year 2012, Dr. Ngozi Okonjo-Iweala disclosed that some oil marketers fraudulently collected $\$ 232$ billion from the Federal Government as fuel subsidy yet cases of those who paid fraudulently and those who received fraudulently are yet sitting on the fences.

Many charges have been leveled against Jonathan administration by Dapo Thomas as follows:-

1. The Chairman, Nigerian Governor's Forum Rotimi Amaechi in November 16, 2013 at Sokoto urged the EFCC to investigate how \$5billion got missing from the Federal Government Excess Crude oil Account. According to him the ECA stood at $\$ 9$ billion by January only to shrink to \$4billion by November, 2013.

2. A Minister was the subject of a petition sent to EFCC by a group called crusaders for Good Governance in August 13, 2013. In the petition the Minister was accused of having spent close to $\mathrm{N} 2$ billion on chartered jets. Yet nothing was heard about what the government has done over it.

3. The Aviation Minister Stella Oduah was accused of spending N 258 million on just two cars. Her case was moving up and down from one committee/panel to the other and it took the President a very long time and perhaps reluctantly to get her off the job.

However, it must be pointed out that in civilized countries once a Minister is alleged like Oduah he or she resigns immediately, but in Nigeria the situation is different.

4. One John Yusuf, a director in the Police pension office or so was sent to jail for 2 years only for stealing $\$ 27.2$ billion belonging to innocent police pensioners. It was also alleged that Yusuf went for plea bargaining, that is he negotiated settlement terms with the government.

Please note that the concrete manifestation of this write up is twofold to wit:

Firstly to show that we have sufficient financial capital if properly managed to pursue the much desired economic objectives as contained in the 1999 Constitution of Nigeria if our leaders would show sufficient uprightness, integrity and probity in office without acts of corruption. Secondly for all politicians and the entire citizens to wake up from their slumber and ensure that our conscious efforts are geared towards the redressing of all these distressing and depressing impediment situations of our national economy and good government.

\section{Re: Economic Objectives: Public and Private Sectors}

It has been asserted by many writers that the pace of economic growth and development of any Nation or Country is usually dictated by the aggregate effect of the activities of both the public and private sectors.

That is why Nigeria practicing a mix economy enshrines in the 1999 Constitutional provisions dealing with its Economic Objectives and thus permitting any person to participate in areas of the economy within the major sector.

And that is why in the same section 16, protections are made for the rights of every citizen to engage in any Economic activities outside the major sectors of the Economy.

By section 16(3) of the said Constitution, a body is enjoined to be set up by an Act of the National Assembly which shall have power

(a) To review, from time to time, the ownership and control of business enterprises operating in Nigeria and make recommendations to the President; and

(b) To administer any law for the regulation of the ownership and control of such enterprises. 
Section 16(4) deals with the interpretation of certain words where (b) "Economic activities" includes activities directly concerned with the production, distribution and exchange of wealth or of goods and services; and

(c) "Participate" includes the rendering of services and supplying of goods.

From all the provisions narrated above, it is crystal clear that successful manipulation of any country in Economic objectives is a function of the participation of both the citizens (private sector) and the government (public sector).

We shall deal more comprehensively with the PUBLIC and PRIVATE Sectors of the economy later on in this work.

\section{The Concept of Public and Private Sectors}

The National Institute for policy and strategic studies (NIPSS) had these to say on the above

Sectors and Nigerian Economic Crisis: "The public sector refers to a combination of central" "government institutions, local authorities, nationalized industries and public corporations." "It refers, in short to the entire gamut of the state's institutional operation in a given" "economy. Contra wise, the private sector constitutes that part of the economy which is" "not within the purview of the state's control or involvement".

Apart from the productive activities of private enterprises, the private sectors also embraces the economic activities of non-profit making organizations as well.

It is a pity that time and space will not permit us to discuss in this paper all institutions within the purview of both the public and private sectors but we are of the opinion that writing later on them generally may be desirable to show their weaknesses and strength since they all have common problems. However as at this juncture, it will therefore be necessary to discuss firstly the common phenomenon that triggered off crisis in Nigeria economy over the years.

\section{Nigeria Economic Crisis}

Nigeria is an agricultural country and in 1960's Nigeria was predominantly an exporter of agricultural commodities but came 1970's, the oil exportation became the main stay of the economy. Oil prices became profitable and alluring as a result of the favourable world oil prices by the OPEC during the 1973 middle-East War.

As at this period the country became very rich, buoyant and healthy. There was money to cater for the building of roads, the provision of health care services, the building of schools and for employment opportunity of the masses.

Everything went on well in Nigeria, and poverty as it is today became unknown.

Nigeria became so rich that money was not her problem but how to spend it. Like a short- sighted man, Nigeria thought that all these conditions would go on for ever and thus concentrated on oil exportation to the neglect of all other products.

Thus because of the oil bonanza, there has been a serious neglect of the agricultural sector which led Nigeria to be importer of food stuffs like rice, wheat and so on to mention a few.

Nigeria forgot at this time that all that glitters are not gold, and that life is not always a bed of roses. There is no permanency of existence in life which is subject to chopping and changes of circumstances; and instead of diversification of its economic products and return to sustainable agricultural practices; it stood firmly in life and death only with the oil exportation.

This structural distortion has affected the economy of Nigeria because the Nigerian economy could not absorb the shocks which were triggered off by the sudden collapse of oil market which started by the middle of 1981 .

The NIPSS informed us that the dramatic fall in domestic oil production coupled with the even more dramatic fall in world price of oil, led to a drastic reduction of Government revenues and foreign exchange earnings. 
This has stampeded the entire country along the path of unemployment, hyperinflation, and closure of industries, stagnation and indeed social unrest with even political instability.

Quoting Aboyade by 1985 the country's GPD was some 15 percent lower than at the beginning of the 1980's and the real per capital GPD and consumptions were even well below 1970 level.

The paper ended up to say that from the Economic Stabilization Act of 1982 which was advanced as an Adjustment package by the civilian administration, to the Structural Adjustment programme under the Armed forces, the Government of Nigeria has continually grappled with the policy of choices which can steer the economy away from the path of collapse and towards one of self-reliant development and social progress.

However the Nigerian government struggled hard to rephrase the economy by getting itself involved in the ownership and management of enterprises in such key sectors as banking, insurance and industry through the promulgation of the Nigerian Enterprises Promotion Decree of 1972. And by1980 there were about 70 Federal parastatals and numerous others at the state level. What however is disappointing in the whole scene is that most of the parastatals have continued to be bedeviled by corruption, mismanagement, nonprofitability and political manipulation so much that they have come to constitute a drain on the increasingly meager government revenue.

Perhaps it may be pertinent to revisit the Public and private sectors in order to know why the public sector has fallen below belt and thereafter make recommendation.

\section{Private and public sectors revisited}

The Economic objectives as contained in the 1999 constitution allows both the state and individual citizen to manage or participate in the economy of Nigeria.

And while the state is to manage and operate the major sector of the economy only, provisions, are made to protect the right of every citizen to engage in any economic activities which are outside the domain of the major sector.

However there is a preponderant or avalanche of evidence to show that the Nigeria workforce is not giving its maximum to the Nation; and that despite the activities of the Federal Government to combat mass unemployment and to promote self-employment and self-reliance by creating the National Directorate of Employment since 30/1/1987, the rate of unemployment has reached a cacophonic dimension which is both incredible, fantastic and astronomical in Nigeria. Millions of our graduates and many youths are jobless without any hope for now or in the anticipated future. This unemployment situation usually leads to the non-payment of any minimum wage, poverty, frustration, anger, youth restiveness, and penury; which may also trigger on to stealing, unwholesome behavior, discontentment, violent conflicts and insecurity. Thus, the much expected maximum welfare, freedom and happiness of the citizens becomes an uphill task.

For now, it would appear as if the fulfillment of the much taunted economic objectives provision is not only a wishful thinking but an illusion.

To make the economic objectives realizable therefore in this perspective, we should urge the public sector to improve by embarking on an extensive and drive which will result both in the highest rate of growth and standard of living in Nigeria.

Although in terms of effectiveness and efficiency, the private sector is alleged generally to be operating better than the public sector and General Nwachukwu gave the following reasons for such a pitfall: in his own words -

(a) Measurability: Productivity is more easily measurable in the private sector, particularly in the productive units, than in the public sector which is usually service-oriented. It is easier to determine performance when it is quantitative rather than qualitative. 

AN UNFULFILLED MISSION OF EXPECTATION

(b) Size: The public sector is a huge machine in terms of authority and responsibilities. It operates in very big units which are more difficult to manage than the private sector which is broken down into smaller manageable divisions.

(c) Degree of Autonomy: It is generally believed that the greatest strength of management in the private sector is the speed with which decisions are taken, communicated and implemented. This is not the case in the public sector, bureaucracy and red-tapism should be de-emphasized. Opportunities should be created for the implementation of constructive ideas from the lower echelon of the service. Public enterprises should be encouraged to be constructive and developmental in their administration rather than adopt rigid rules which give no room for flexibility. Parastatals need to be autonomous. It is in this regard that the Federal Government has granted most of the agencies functioning under various Ministries, some degree of autonomy to make for efficiency and effectiveness in the performance of their duties. Perhaps there is a case for more/ complete autonomy for government parastatals thus removing the strangle hold of bureaucracy in order to facilitate quick and efficient implementation of decisions.

(d) Absence of Competition: Basically, the public service by its nature, it is not a competitive enterprise. It grinds slowly but surely. However in a developing economy like ours speed and competitiveness are of essence. Fortunately, competition is gradually creeping into our public sector. For example, the courier services in the private sector are a challenge to the Nigerian Postal Services. Also the private airlines are competing seriously with Nigeria Airways. Allowing the public sector to be faced with these kinds of competition is a very healthy factor for improved performance and hence improved productivity.

(e) Profit Motive: This is generally absent in the public sector. Hence the laxity in the performance of the public sector whose wages and benefits are not necessarily determined by the amount of profit made by the organization. This factor to some extent has influenced the attitude of the Nigerian public servant who believes that whatever his performance, he would get his pay at the end of the month. One invariably finds a lack of incentive or motive in a situation where one does not look forward to some increased benefit due to increased profit-margin. However, lack of profit-motive should not be the public sector excuse for not improving performance.

\section{Economic Objectives and the Niger Delta people}

The oil and mineral resources upon which Nigeria government depends mainly for her economy comes from the Niger Delta area of the country, but it would appear as if the Federal Government has not been all that successful to properly harness the resources of this area in order to promote National prosperity, or efficient, dynamic and self-reliant economy for the people of the area over the years.

As a matter of fact it must be noted that the production of oil, distribution and exchange of wealth or goods in the area has been the exclusive reserves of the Federal Government under the joint venture operation with the multinational companies to the exclusion of the oil producing communities.

The 1999 constitution also has compounded the problem by vesting the control and ownership of oil mineral resources found below the land of individuals or communities on the Federal Government despite the common law provisions.

The implication is that rents, bonuses and royalties are usually being paid to the Federal Government at the expense of the true owners of the land.

To worsen the position, the payment of compensation to the people whose lands have been compulsorily acquired for oil prospecting activities in the area leaves very much to be desired.

The people thus feel cheated and alienated from their country, Nigeria.

They sometimes fund it hard to buy food and other necessary components to exist.

There is no equitable dealing with the people of this area and neither has the question of inequality and social justice been met adequately. 
Consequently, as far back as 1980s frustration, unhappiness, abject poverty, improverishness, environmental degradation and many more have been the lot of the people in this area.

There is in fact a loud cry of poverty in the Niger delta area. One hears it in the agony of the jobless, the weariness of the old and the failings of the young.

And unless the Federal government takes an holistic view in solving the recurring problems prevalent in the area, the much welcome economic objectives contained in the 1999 constitution may be an illusion for the building of an envisaged just society which is both indivisible and indissoluble.

The Federal Government should adhere to the words of Abraham Lincoln who said as follows:

"The legitimate object of government is to do for a community of people whatever they need to have done but cannot do at all, or cannot so well do for themselves in their separate and individual capacity”. followings:

And although the Federal government has set up from one time to the other the

Niger Delta Development Board (NDDB) in 1959, Oil Mineral Producing Area Development Commission (OMPADEC) 1992 - 1999 and Niger Delta Development Commission, (NDDC) 2000 to date.

These agencies, appear to be ineffective and that was why the establishment of Delta State Oil Producing Areas Development Commission (DESOPADEC) has been established in year 2007 by the Federal Government to address the problems of the oil producing communities in line with its economic objectives which are contained in section 16(2)(a)(b) and (c) of the 1999 constitution as follows:

(2) - the state shall direct its policy towards ensuring -

(a) the promotion of a planned economic development;

(b) that the material resources of the nation are harnessed and distributed as best as possible to serve the common goal,

(C) that the economic system is not operated in such a manner as to permit the concentration of wealth as the means of production and exchange in the hands of few individual or of a group.

"So far, the economic objectives of Nigeria are generally unfulfilled mission of expectation and particularly when the plight of the Niger Delta people are considered. Damfebo, K. reported as follows:

"The people's lives are being terrorised daily by the movement of earth shaking "explosive, heavy duty equipment and vessels."

"The sources of water are polluted, water fronts constantly being corroded; fishing gears and farming foods destroyed. diseases".

"While the entire environment is endangered and the people are exposed to avoidable

With all these, one may conclude that suitable and adequate shelter, suitable and adequate food, reasonable national minimum living wage, old age care and pensions, and unemployment, sick benefits and welfare of the disabled which are the hall mark of the country's economic objectives by section 16 (2)(d) have eluded people in this area very predominantly.

It is therefore our hope that the body set up to review from time to time, the ownership and control of business enterprises operating in Nigeria will be bold enough to make recommendations to the President in order to effect changes which will impact positively on the lives of the people particularly in this area.

\section{Inequality of Opportunities and welfare Services}

By section 16 (1)(b) of the Nigeria constitution it is provided that the state should control the National Economy in such a manner as to secure the maximum welfare, freedom 
and happiness of every citizen on the basis of social justice and equality of status and opportunity.

This provision although is salutary and grandiose, yet it looks like a complete illusion in application since Nigeria is a country where in-equality of opportunities prevails.

It is not a welfare state where a government for instance provides money, free medical care, housing, and good living conditions to its people including (those that are not employed) or old to work. It is a place for the survival of the fittest, where everybody is on his own to look for means to exist. As a matter of fact, it is a place where millions of naira belonging to the pensioners are sometimes stolen with impunity through administrative swindling.

How can the welfare of the people be sustained when the government looks insensitive to their needs and plights.

The disparity between the "Haves" and the millions of "Have Nots" is predominant and worrisome which usually leads to the commission of nefarious acts like, stealing, with such horrendous acts like robbery, assassination and so on.

With all these mishaps, one is in doubt if Nigeria really practices Democracy in the actual sense, since democracy in its simplest form is a system that ensures a minimum of a welfare state which guarantees a living condition, food, accommodation, clothing, education for the children and municipal services which Nigeria lacks as at present. It is when the citizens are well taken care of, properly empowered and provided with all amenities to improve their living condition that one may talk of democracy.

It is hereby suggested that the Government should therefore take care of its citizens properly in order to achieve the golden objectives that are contained in the constitution.

Also if we are to reap the dividends of democracy and pursue to the letters the economic objectives, the management and operation of the major sector of the economy should be handled by people who are transparently honest and hot by the buffoons and mindless plunders of the treasury.

The management and operation should in fact be handled by those who believe that political sovereignty is but a mockery without the means of meeting poverty, literacy and disease.

Therefore a situation where an agency of the government looks like a haven for corruption and inefficiency calls for a serious rebuke in this country.

Take the case of NNPC at the risk of repetition and criticism.

The Nation paper of the $10^{\text {th }}$ February 2014 is much explanatory on this.

The NNPC is alleged of stealing \$20 billion of oil money which is a serious breach of the anti-anti-graft legislation and international obligations including the U.N. convention against corruption and the African Union convention on preventing and combating corruption both of Nigeria government has ratified.

Sanusi, the then governor of the central Bank alleged that the NNPC is operating a racket through which the Federation has been losing billions of dollars.

He explained that the NNPC is yet to account for $\$ 20$ billion (equivalent of N3.25 trillion) from the total of $\$ 67$ billion oil sales receipts from January 2012 to July 2013.

It is suggested that stealing of this money/sum from the economy of Ngieria that is already weakened by corruption will jeopardize sustainable development and hurt ordinaryNigerians who rely on the government to provide basic necessities of life such as water, good roads and electricity.

This nefarious act does not augur well for a country who has such beautiful economic objectives, and it is no less than a brazen lootery of the treasury when particularly the NNPC is said to be without power to spend any money without appropriation.

The Economic Objectives of the state has failed woefully for a failure to control the National Economy well in this circumstance and in such manner as to secure the maximum 
welfare, freedom and happiness of every citizen on the basis of social justice, and equality of status and opportunities.

At least the alleged stolen and or unaccounted for amount, would have been used to cater for the realization of the economic objectives.

Finally to be noted is that it is absurd to do this particularly when our oil is sold for $\$ 30$ above the bench mark price while the foreign reserves and the excess crude oil account are going down.

It is therefore suggested that if the laudable economic objectives would be properly achieved, Nigerians must imbibe the idea that government (apart from many other factors) consists that politicians should take offices as public trusts that are bestowed on them for the good of the country and not for the benefit of an individual or party. They should shun corruption and greed in order to cater for the masses; while our government should realize according to John Ruskin that the first duty of a state is to see that every child born therein should be well housed, clothed, fed and educated till it attains years of discretion;; while a good government in its entire ramification should endeavour to provide good housing, employment, water, comfort and happiness for its entire citizenry.

According to Obasanjo " the state enterprises should not be poorly run, since they give way to and exacerbate corruption in our economies.

"Therefore qualitative and quantitative resource management within the framework of a mixed economy which possesses in-built and autonomous mechanism for equity, empowerment and capacity building in which access to the system is open, free and equal should be encouraged".

Thus it is hereby opined that although the 1999 constitution contains laudable provisions on economic objectives, yet it is enjoined that we should not love it in words alone, and neither love it by the tongue, but we should love it in deed by action realizing the fact that science without religion is lame, while religion without science is blind.

\section{Economic Objectives and provision of welfare services}

By the Constitution of Nigeria under the Economic Objectives, it is provided that the State shall direct its policy towards ensuring that suitable and adequate shelter, suitable and adequate food, reasonable National Minimum living wage, old age care and pensions, and unemployment, sick benefits and welfare of the disabled are provided for all citizens.

Again as laudable as these objectives are, it is a matter for regret that they have not been properly achieved in Nigeria.

Thus extreme poverty remains an alarming problem in Nigeria despite its bright provisional economic objectives, including the efforts of the Federal Government.

This poverty has been caused probably by the harmful economic system of the country and the inability to impact positively on the lives of its people by the Federal Government coupled with an unequal income distribution. As remarked earlier, there is in fact loud cries of poverty in the entire country which one hears in the agony of the jobless, the weariness of the old people and the failings of the youth who often find it hard to buy food.

In addition to this, the rate of unemployment has risen to an intolerable height of discontentment, unhappiness and disillusionment; while housing facilities/projects which started in the Shagari era had been abandoned on political grounds. There is nothing like old age cares as one may find in developed countries or welfare states.

Every citizen is left on his own to struggle for existence.

The plights of the common man are many and worrisome. Not many hospitals are built with the resultant concrete manifestation of diseases and deaths.

There is darkness everywhere owing to epileptic supply of electricity. No appreciable improvement is to improve both the social and economic conditions of the people, while roads are like death traps on majority of routes in Nigeria. There is insecurity here, there and yonder which often destroys the stability of sound political and social policies. 
It would even appear as if private initiatives which are the frontiers of development are not properly encouraged while there is a blow to agricultural development in the rural areas.

All these and many more have constituted themselves as impediments to the realization of the Nigerian economic objectives.

Lastly, one may write more on the spate of insecurity in Nigeria which has prevented to a considerable extent foreigners to do business with us.

However this insecurity may be associated with poverty, hunger illiteracy, corruption, unemployment, lack of good economic conditions, inherent inequalities in the society and lack of visionary and effective leaders. Although government is doing its best to prevent the spate of insecurity yet no permanent or effective solution has been reached notwithstanding the fact that no society can experience its economic objectives and development when insecurity prevails and where mob rule has become predominant.

Therefore the government must evolve certain policies and strategies to ease the problem of poverty, illiteracy unemployment, and corruption.

The government should also make it a life imprisonment or death penalty for anybody who is found guilty of corruption which has hitherto corroded and destroyed all democratic mantles and processes in Nigeria and thus culminated to unrealisation of its economic objectives.

\section{Conclusion}

This work has shown that Nigeria has beautiful economic objective which has not been achieved owning to many factors discussed herein.

Government has not been able so far to improve the living standard of its people owing to poverty, unemployment, lack of good housing facilities, corruption, lack of cares for old age, insecurity and malfunctioning system of pension payment. This work therefore recommends, as follows:-

1. Since inequality is a potential threat to the National security, the government should try as much as possible to move towards the direction of a welfare state which makes adequate provisions for alleviating poverty at all levels and which is our economic primary objective.

2. In order to promote government and welfare of all persons as envisaged by its economic objective, the government must make chapter II of principles of state policy justice able - like South-African Constitution. This will allow any person to sue the government when there is any possible breach of this CHAPTER.

3. We implore our leaders to follow the footsteps of Nelson Mandela as enjoined by Asiwaju Tinubu as follows:

"Mandela was an African leader who never coveted power but used power

for the good of the greater number of the people. Mandela left a legacy of quality leadership, selfless service, and a people centred government"

4. Our leaders must realize that as long as poverty, poor living conditions, illiteracy, injustice and gross inequality persists in Nigeria, none of us can truly rest, and insecurity will be a hard nut to crack, or a despicable disaster to overcome or eradicate..

\section{References}

1. See a paper titled: The Quest for Economic Recovery: Public and Private sector in Nigeria presented by the National Institute for Policy and Strategic Studies (NIPSS), Kuru at the National Conference on improving the performances of the Public Sector held at the University of Ife, $21^{\text {st }}-23^{\text {rd }}$ April, 1987.

2. Nwachukwu Brigadier (1987) - An address to the Annual faculty Workshop on Improving

Public sector performance in Nigeria Unife April 21 - 23, 1987. 


\section{A. T. Oyewo}

3. Oyewo, A. T. (2013): Corruption and Democratic governance in Nigeria being an article submitted for publication.

4. El-rufai (2012): Between Terrorism and Corruption Implication for Nigeria - being a text of paper delivered at the Lead City University, Ibadan 2012.

5. Oyewo, a. T. (2013): Corruption and Democratic governance in Nigeria being an article submitted for publication.

6. Patrick Wilmot (2007: Interventions (Ibadan): Book caft at p 40.

7. Nzeogwu: was quoted by Prof Nwoke in his inaugural lecture at the Lead City University, Ibadan. $7^{\text {th }}$ November, 2013.

8. Achebe - was quoted by Prof. Nwoke, Ibid.

9. Nwoke (2013): $3^{\text {rd }}$ Inaugural lecture delivered by him at the Lead City University, Ibadan (10)Tambuwal: The Nation Tuesday 10 December 2013.

10. Dapo Thomas. The Nation 8 December, 2013.

11. Aboyade was quoted in the paper submitted by the NIPSS to the UNIFE Conference of April, 21 - $231987 \ldots$. Op cit.

12. Abraham Lincol was quoted by Dokun Gaiye in the Wisdom Diary book of Notable quotations - by Dee Publishers, Osogbo Nigeria, (2006).

13. Dan febo, (2014): Legal regime of Compensation for Victims of Oil and gas operations in Nigeria, being a Ph.D. Thesis submitted to Ambrose Alli University, Ekpoma, Nigeria.

14. The Nation of the $10^{\text {th }}$ February, 2014.

15. Obasanjo (1993) Hope for Africa.ALF Publication, Abeokuta, Ogun State. 